\title{
Written Out of Life: The Death of Keith Vaughan and his Journal
}

\author{
Alex Belsey \\ King's College London
}

\section{ABSTRACT}

When the British painter Keith Vaughan (1912-77) ingested a lethal cocktail of barbiturates, having made the decision to end his life after a long struggle with cancer, there was only one thing left to do: write one final entry in his journal, the lifelong literary account he had commenced in 1939 and maintained ever since. Vaughan's journal is an extraordinary document, its 61 volumes spanning 38 years of impassioned ideas and personal development from his difficult wartime years as a conscientious objector through his post-war life as a successful but troubled artist.

This paper focuses on the final volume of Vaughan's journal, commenced in August 1975 and ending on the morning of 4 November 1977. It considers how Vaughan used journal-writing at a time of great suffering to reflect upon his life and his reasons for leaving it. By revealing the crucial role that Vaughan's final volume played in justifying that his life had ceased to have forward momentum or meaning, this paper argues for the close relationship between the practice of journal-writing and questions of futurity, positing Vaughan as an exemplary author-subject who uses diary or journal forms to postulate a potential future and their relationship to it.

Keywords: Keith Vaughan, journal, diary, British art

On the morning of 4 November 1977, the British painter Keith Vaughan (b. 1912) ingested a lethal cocktail of barbiturates and thus ended his life. Vaughan had just enjoyed an evening with close friends and had recently set his affairs in order and penned personalized goodbyes; the only thing left to do was make one final entry in his journal-his first in five weeks. 
Vaughan had spent two years suffering from bowel cancer and the various medical treatments he had undergone to fight it. The final volume of his journal chronicles a life that had become 'hell' or simply a 'non-life', leading him to lament his 'sheer daily misery' (02.04.1976; 73). ${ }^{1}$ Vaughan records the pain, discomfort, and degradation of his reduced state whilst scolding his long-term partner, Ramsay, and seeking escape through reminiscences of years and journal volumes past.

Vaughan's journal is an extraordinary document commenced in August 1939 and totalling 61 volumes in all. It consists of almost 5,000 pages spanning variously sized notebooks and written in generally small script with varying degrees of legibility. The journal was Vaughan's companion throughout the difficult wartime years of 1939-45, when his moral commitment to conscientious objection led him first to the St John Ambulance service and then to the Non-Combatant Corps, before he was finally stationed at a prisoner of war camp. During those years of barrack life in the English countryside, he felt his removal and distance from (hetero)normative society and its expectations most acutely, making his journal the highly romanticised account of a sensitive, artistically inclined young man struggling to find a place and a role in the world. Vaughan's journal entered a fallow period in the post-war years as he attained the successful life of a painter to which he had aspired since his schooldays. When Vaughan, in the late 1950s, seemed to arrive at a point of dissatisfaction with his settled and comfortable life, his journal-writing resumed with the intensity of his anguished youth, reaching a height of excoriating self-analysis and raw emotional expression in the early to mid-1960s.

Following Vaughan's death in 1977, the journal volumes passed into the possession of his friend and executor Alan Ross, the esteemed editor and publisher who had first approached Vaughan to self-edit a selection of journal entries for publication as an illustrated book, resulting in Vaughan's Journal E $\mathcal{E}$ Drawings published in 1966. This handsomely presented volume offers a streamlined version of the narrative that Vaughan crafted throughout the many years and volumes of his journal-writing: a story of an individual's continual self-construction and reconstruction through their developing relationships with, and perspectives on, the world around them and the art, literature, and philosophy that helped them make sense of it. As I argue in my monograph Image of a Man: the Journal of Keith Vaughan (2020), the journal should be considered 'a literary text and a major creative work in its own right', an exemplar of how diary and journal forms can develop and demonstrate the evolving subjectivity of their author-subject. ${ }^{2}$ However, Image of a Man stops short of reading the journal volumes of the 1970s in any detail, as by this time there was little uncharted territory into which Vaughan entered to further develop his identity as an artist, having taken his subversive 
autodidacticism and experiments in playing the outsider to their limits. Instead, the most interesting aspect of Vaughan's relationship to the journal in the 1970s was his re-reading of previous volumes, which led him to survey and annotate the key subjects and themes of each volume in 1974. In his book Drawing to a Close: the Final Journals of Keith Vaughan (2012), Gerard Hastings reproduces the unabridged text of Vaughan's sixty-first and final volume with extensive notes, analysis, and illustrations. Hastings' book powerfully conveys the sense in which the final journal volume is a prism through which we, and indeed Vaughan himself, can view his life and work in retrospect, infused as it is with 'the nostalgia that Vaughan was experiencing in his final years.' ${ }^{3}$

This paper is similarly focused on the final volume of Vaughan's journal, commenced in August 1975 and ending with the entry made on the aforementioned morning of 4 November 1977. Rather than using the final volume as a means of reappraising Vaughan's life and work, this paper considers how Vaughan used the practice of journal-writing at a time of great physical and emotional suffering to reflect upon his life and his reasons for leaving it. Close textual analysis of the final volume, contextualised by consideration of previous volumes, reveals the crucial role that Vaughan's journal played in justifying to him that his life had ceased to have forward momentum or meaning-and that taking his own life was the only honourable and appropriate act available to him. Life-writing and death are familiar bedfellows, with the prospect of the latter prompting the sense-making and pattern-seeking practices of the former. We find this movement through patterns in memoirs such as Gore Vidal's conversational, non-linear and aptly-titled Point to Point Navigation (2006), written as its author felt himself moving 'toward the door marked Exit' and navigating through the settlement of various scores, personal and political; it ends with Vidal's reminiscence of quoting the closing lines of Alexander Pope's Dunciad way back when he was a teenager in 1943, thereby closing the circle. ${ }^{4}$ But it is not only the retrospective (and somewhat stately and privileged) practice of writing one's autobiography or memoirs that is prompted by ruminations on the fact and imminence of death; as life-writing theorist Philippe Lejeune has suggested, a fear of death lurks beneath the need to ensure that a journal or diary continues as the affirmation of the continuation of life. ${ }^{5}$ The poet and compulsive diarist Sarah Manguso, in her 2015 book Ongoingness: The End of a Diary, asserts that, 'Imagining life without the diary, even one week without it, spurred a panic that I might as well be dead. ${ }^{6}$ The temporal framing is key; Manguso not only fears losing what has taken place in the past, but worse still she is in thrall to an imagined future in which she has been an inadequate scribe and has too little to show for her life. 
This paper argues for the close relationship between the practice of journal-writing and futurity, positing Vaughan as an exemplar of the author-subject who has entered into a symbiotic relationship with their journal in terms of negotiating past, present and future. In correcting long-held, and sometimes dismissive, assumptions that journals or diaries are only concerned with recording the past, Lejeune describes the writing of these texts as 'progressive', moving forward by 'digesting the near past and filling the near future with plans'; with its 'dynamic, forwardlooking image', the journal or diary is 'always on the very crest of time moving into unknown territory'. ${ }^{7}$ That this territory should be unknown is crucial to the writing of a journal or diary, for it prolongs the journey, ideally indefinitely, by refusing to name or make clear its destination. As Julie Rak explains, the future, as the 'ultimate addressee' of the diary, 'must always be a horizon, since the diarist will never reach it'. ${ }^{8}$ Manguso may insist that the content of her own diary 'foreshadows nothing' and therefore has little role in anticipating a future, yet there are many instances in Ongoingness where she suggests that this very obfuscation was responsible for her diary's (admittedly painful) longevity—and that her diary-writing has helped her contend with matters of time and finitude (see, for example, her mantra-like statement: 'Remember the lessons of the past. Imagine the possibilities of the future'). ${ }^{9}$ This paper reveals how movement toward an unknowable future, glimpsed as a receding horizon, was key to the long and productive relationship that Vaughan had with his journal, the two sustaining one another for 38 years. In his final years of illness and pain, having developed his identity as a man as an artist by becoming a journal-writer par excellence, Vaughan had to write himself out of life if he was to decide to die.

\section{1. 'I CANNOT SEE HOW THIS WILL END'}

Vaughan had always considered his relationship to the world and those around him in terms of insecurity and precarity. The sense that the future is ominous and uncertain, and that he may be ill-equipped for what it holds, informed the very first journal entry dated 25 August 1939. As war in Europe seemed inevitable, he feared that his conscientious objection would cast him as a 'coward' and that he would thereafter be regarded as 'loathsome, despicable, and unfit for human society'. ${ }^{10}$ In this first entry, Vaughan drew upon the experiences and disappointments of the past-specifically, his sense of exclusion and ostracization from normative conceptions of masculinity and therefore societal value-as justification for his current situation, before positing the difficult problem of how he will cope in the future. As with much of the journal-writing 
that would follow over the weeks, years and decades, what may initially seem like an overly pessimistic and unhelpful picture of his situation was in fact a productive way for Vaughan to sustain the impetus for his own development or self-construction-and therefore prolong the practice of journal-writing into the future. Vaughan commenced his journal at what he insisted was a point of crisis; in order to feed this spark of inspiration, he alluded throughout the early volumes to his 'failure' thus far in life, in one instance declaring that, 'The purpose of this autobiography is to try to understand and account for my failure in life.' ${ }^{11}$ Vaughan often wrote of impending threats in the near future-war, romantic disappointment, rejection-but it is more instructive to consider him writing of a satisfactory and fulfilling future receding further beyond the horizon, out of sight and certainly reach, but still out there to be found.

Through his reading and theorizing about artists including Cézanne, Seurat, and Picasso, which was crucially given shape in long exploratory tracts of his journal-writing in the early 1940s, Vaughan became convinced that his own visual art practice needed to harness a similar productive tension. His sketches, ink drawings, and oils of nude male figures, sometimes alone and adrift, sometimes gathered in groups or 'assemblies' in ambiguous landscapes or interiors, were attempts to fix unstable elements to produce a picture that retained the marks and stresses of the artist's labour in that moment. This was not so much about physical labour as it was the philosophical struggle of pinning the presence of another (invariably male) body-for Vaughan the symbol of humanity and what it means to be human-to the canvas. As Vaughan developed his visual practice through the $1950 \mathrm{~s}$ and into the $1960 \mathrm{~s}$, the distinction between figuration and abstraction became eroded by an increasing adventurousness in composition and the handling of paint. Early pictures such as Assembly of Figures or Green Bathers, both from 1952, resemble conventional bathing pictures with their thoughtfully posed and contained figures. Figure in a Red Room (1956) evidences an evolution, predicting the later monumental figure paintings of 1958-62 with its 'De Staël-like use of blocks of colour to modulate the surface of the body', making the figure and its environment more closely interrelated, as if constituted by the very same stuff. ${ }^{12}$ By Landscape with Figure: Morelos (1959), the male figure is faceless, depersonalised, a mere suggestion formed by planes of colour. The 1960s, with pictures such as Two Bathers or Laocoön Figure (both 1964), saw arguably the apex and full realisation of Vaughan's ambition to paint pictures that evoked fleshliness through frisson and energy, creating an art of immediacy and pure sensation. ${ }^{13}$

To achieve the breakthroughs of the late 1950s to mid-1960s, Vaughan had cultivated his states of productive tension by writing in his journal of the experiments in sensation that he was conducting in his home studio 
at Belsize Park, London. These had been undertaken to alleviate a crisis of boredom and Vaughan's fears of having become passé, thereby giving him a renewed sense of subversive energy. Vaughan was experimenting with techniques he variously described as 'onanism', 'autoeroticism', and 'autosex', seeking a sexual experience that was 'isolated as a subjective sensual pleasure, unalloyed by personal relationships with another'; this often involved use of electrical stimulus, self-flagellation, or various other pursuits of pain. ${ }^{14}$ To maintain tension and frustration, he would often protract these practices and delay (or outright deny) his ultimate gratification, making the experience 'like a sort of ordeal'. ${ }^{15}$ Just as the pleasure of further unexplored territory lay just beyond the horizon, so too did danger, which was always, crucially, unspecified; concerns about the effects of such practices, which Vaughan likened to drug addiction, were frequently voiced in such caveats as, 'I fear I cannot avoid paying for this in deterioration of physique \& mind.${ }^{16}$ Vaughan was experimenting with power and powerlessness-whether outwardly, when involving the young men like Johnny Walsh who frequented his studio, or internalised in his solo sadomasochistic practices, with the subsequent, ritualistic journalwriting describing their effects and after-effects in meticulous detail. These experiments, and the productive fantasies that swirled about them, depended greatly upon the articulation through journal-writing of disappointment and frustration with the past, of agitation in the present, and of continually deferred promises and perils in an uncertain future.

By 1975, Vaughan had been living and working as an artist for around 30 years. He had been living at his home in Belsize Park since 1952 and had been in a relationship with his partner, Ramsey McClure, since 1948. Their relationship had seen its share of tumultuous times, with Vaughan's complaints in his journal-writing of feeling stifled by (or shackled to) Ramsay fuelling much of the productive tension of the 1960s. There were heated arguments when Ramsay had found and read from the journal, prompting Vaughan in 1964 to pen a particularly vitriolic entry that sniped at Ramsay's compulsion to 'pry into my secrets-and let me know he has pried', before excoriating his partner's 'boring, inept, incessant presence' in case Ramsay should ever pick up the journal again and read those words. ${ }^{17}$ Nevertheless, by 1975 this was a situation that had remained much the same for years, as was Vaughan's continued self-medication with prescription drugs, alcohol, and 'autosex' as recorded in his journal. With the completion of renovations to their second home at Harrow Hill, Essex in 1965, there was also a peaceful retreat available to either or both parties, a place where Vaughan painted some vividly evocative, abstracted landscapes during the 1970s and produced the 1974/75 Mahler sketchbook of portraits and erotic drawings. ${ }^{18}$ The first entry in what would be 
the final volume of Vaughan's journal, dated 11 August 1975, consists of only a few lines reporting on his current (and improved) state, in which he feels 'more active and libidinous' (1). This is a fairly typical opening to a new journal volume, with its sense of purpose and promise of productive tension and release. Vaughan announces, 'Would like to have some large canvases here ready. No hurry. Better to let the pressure build up.' Again, this is a typical strategy employed in Vaughan's journal-writing that establishes a present agitation or 'build up' by deferring the future in which he will truly express himself-but which in retrospect gives no indication of the painful incapacitation to come.

In early 1974, Vaughan had experienced an acute pain after having dinner with his dear friend and fellow artist Prunella Clough. An investigative enema revealed nothing, but he was later diagnosed with an enlarged liver and a kidney stone that required removal. Following the operation in 1975, he returned to the cottage at Harrow Hill to recuperate, writing the following suicide fantasy in the journal entry dated 23 August:

Upwards through the roof of the mouth would blow out the back of the cranium \& cause instant death-(or oblivion). If it didn't there might be time to try a sideways shot through the temples. (Impossible to imagine it through the eye or the ear.) (2)

It is alarming that, after what was certainly not a life-threatening or even life-altering procedure, Vaughan was contemplating in vivid detail how to kill himself. There is no evidence that he had access to or much knowledge of firearms, making this an instance of truly morbid imagination. Yet he had been suffering from depression and anxiety attacks for years and had been analysing them at length in his journal since at least the early 1960s. During that period, he had made his attempts at self-analysis through journal-writing (informed by his extensive readings of Freud and other major psychoanalytic researchers) part of an art practice in which he, alone in his home studio, attempted to access and paint from his inner life. Suicide had been entertained to varying extents, though mostly offhandedly, on several occasions years before, but in this 1975 entry we find the most pronounced consideration yet-and at a time when suddenly it seemed to Vaughan that a new phase of his life had begun: one of illness and incapacity that threatened the kind of independent (and, in his own words, 'self-indulgent') life he had lived up to that point. ${ }^{19}$ Being trapped physically compounded the state of emotional entrapment that he had felt with Ramsay for at least two decades. This is apparent when the same journal entry quickly moves from a suicide fantasy to one of burning down the house with them both in it, 'the guilty and the soppy 
innocent' as he refers to himself and Ramsay respectively. He imagines not just killing Ramsay, but brutally beating him to death:

The crash of a fist in the face splintering the thin nasal bones [...] Pounding of hard bleeding fists into the dislocated jaw \& swollen eye [...] to silence that nagging bitching voice of $\mathrm{R}$. [Ramsay] with 2 thumbs pressed deep into the trachea $[\ldots]^{20}$

'Possible? Desirable?' he asks. 'Think it rather than do it', he resolves, confirming the journal's importance as a secluded space in which he could indulge even his cruellest thoughts.

This entry ends with Vaughan describing 'this constant nagging pain at the back of the skull as though waiting for the bullet' (3). Here Vaughan imagines himself to be awaiting a death sentence; even at a time before his eventual cancer diagnosis, but after a procedure intended to relieve him of recent physical pains, he imagines that his race is run. We could interpret this vague suggestion of a future threat, and the evocation of a phantom pain or agitation in the present, as a familiar attempt by Vaughan to refigure recent events and his long-standing hypochondria into a need for productive tension, a catalyst for action. It was certainly becoming ever more difficult for Vaughan to galvanize himself and produce work of which he could feel proud. The short journal entry dated 6 Sept 1975 neatly summarises his state of stagnation: 'I do a little painting each morning. Not much. And I don't believe in it. $240 \times 36$ \& 2 $36 \times 28$ since I left hospital' (6). Vaughan is relatively consolatory towards Ramsay, who 'is obviously ill but seems to try. At least he spends most of the afternoon \& evening in bed. I do most of the cooking. That I don't mind'. ${ }^{21}$ The clipped syntax and muted, almost offhand expressions of opinion convey an inertia and emptiness to Vaughan's situation. He ominously declares, 'I cannot see how this will end', distancing the future as fearful and fatal yet crucially obscured, in doing so injecting the required suspense to propel the journal forward into another day in which to live and write.

\section{2. 'NOTHING I WANT TO DO OR LIVE FOR'}

On 18 September 1975, Vaughan recognizes the incipient bowel cancer, describing his extreme discomfort sitting and laying down. Examining himself with his finger, he identifies 'a hard polyp like growth' (9). On 24 September, now truly convinced he has cancer, he writes, ' $R$. increasingly impossible to deal with [...] And the thought of the endless days \& 
years ahead (for he cannot be got rid of) like a growing cancer-eating out what little healthy tissue I have left' (10). Here Vaughan figures his life with Ramsay as a threat equal to that of a tumour: Ramsay is his other cancer. ${ }^{22}$ Vaughan's willingness to invoke cancer here suggests that the prospect of the disease did not seem alarming or perhaps even upsetting, rather the physical manifestation of the degradation he believed he had been undergoing for quite some time-perhaps even the 'deterioration of physique \& mind' he had predicted (and feared he deserved) back in 1958. His reference here to expecting 'endless days \& years ahead' nevertheless pushes back the dreaded horizon, albeit in response now to a more tangible and existential threat than Vaughan had faced before. However, the journal was now fulfilling the prophecy of years and decades previous as it chronicled the toll on Vaughan's body and the stress on his thoughts; on 6 October he writes, 'The feeling that one wants to shit but nothing to excrete. Anxieties of cancer etc.' (13). This is immediately followed by, 'R. gets steadily worse, more impossible. I cannot get the situation into focus. Much of his accusations against me are true.' Although Vaughan gives a brief explanation of the nature of these accusations, which relate to his 'aggressive' reactions towards Ramsay when bored and bothered, much is left unsaid here. This is consistent with a strategy in Vaughan's journalwriting whereby he withheld certain details or left questions and mysteries dangling as if teasing an expectant reader, thereby securing the future of the journal with a suggestion of further disclosure to come. Whilst here there was a possible reader with Ramsay snooping in his studio, such teases were primarily playing with literary effect to suggest that selectivity was related to self-knowledge (and perhaps its limitations).

A few days later, in a shorter entry of just three brief paragraphs, Vaughan finishes by writing:

M. comes out of hospital on Tuesday, So I've got till then. R continues to be an extra burden. My bowels \& rectum pain me each morning. I sleep badly \& wake in panic. The day is passed in minor chores \& too much drink. There's nothing to live for. But I have no means to end it. $(10.10 .1975 ; 16)$

The 'M.' to whom he refers is his mother, Gladys Vaughan, who by this time was in her nineties. Her doting presence and suffocating sense of concern had been bemoaned by Vaughan since the earliest days of his journal-writing; now, she and Ramsay formed a double burden of dependency that drove Vaughan to despair. It is significant and surely calculated that the stresses they both place on Vaughan are foregrounded in these few lines before he proceeds to detail his physical ailments. There is the assertion here of no remaining reason to live, however Vaughan claims to 
'have no means to end it', therefore prolonging the struggle, perhaps to see whether it leads to some new and potentially productive experience. Yet two weeks later, he confesses:

The more I want my life to end-having nothing I want to do or live for \& nothing but what seems problems \& pain ahead of me-the less able I feel to commit suicide (supposing I had the means). I have not even got a relationship with death. $(21.10 .1975 ; 21)$

In this elaborated declaration of malaise, Vaughan asserts that he has 'nothing to do or live for', the present providing no challenge or demand for action. He alludes to 'problems', so often a productive prompt for him (as, indeed, 'pain' had been), yet does not detail them or even allude to a line of enquiry as he once did. Following this, Vaughan claims that he has 'no relationship with death', a strangely paradoxical statement considering that, in retrospect, we appreciate that his journal-writing on subjects of life and death prepared him for his eventual suicide. But when we consider that Vaughan was ever the apolitical self-styled outsider-a homosexual man, a conscientious objector, an atheist-it is unsurprising that he might claim an unfamiliarity with conceptualisations of death and dying, having not inherited or acquired them through commonplace cultural or religious beliefs. Upon this premise, the only honourable and acceptable death, therefore, is that which occurs when life itself has become dishonourable. Illness and incapacity for Vaughan equal indignity and, as attested in his admission of the truth in Ramsay's accusations, he is living a life that is profoundly compromised.

Upon finally receiving the diagnosis he had been expecting-indeed, for much of his life-Vaughan heads the journal entry dated the following day, 22 October, with the words, 'CANCER ERA BEGINS' (21). Here he writes a passage with advice to his executors: 'Regarding the disposal of my body. Any part which may be used should be removed \& put to such purpose. The remains should be treated as garbage \& disposed of with the minimum of ceremony as allowed by law' (22). It is important to note that the journal had, since at least as early as a journal entry in 1959, been intended in the event of Vaughan's death to pass to Alan Ross, being the true account or complete 'body' representing Vaughan's life; meanwhile, his physical body is to be regarded as useless and unceremoniously thrown away. ${ }^{23}$ Vaughan proceeds to reject the idea of living 'with a plastic bag of my own shit attached to my waist' and plans instead for 'a graceful exit'. This entry ends with the declaration, 'Since I have lived mostly alone it seems reasonable to die alone. I can see that it could have worked out better in other ways. But they didn't come my way.' Here we find Vaughan in a less brittle and more wistful, melancholic mood. 
He had always, throughout the preceding 36 years of journal-writing, felt himself at a remove from life; now, this illness had seemingly arrived simply to continue the process. The less dignified his life, the more dignified his words needed to become and the more authoritative the argument to remove oneself from life altogether. Vaughan had always experimented through journal-writing with removing himself-from politics, social expectations, the emotional demands of relationshipsso whilst the result of one final removal would be far more drastic, he was certainly well-rehearsed in the rhetoric of protest that balanced fatalism with empowering self-awareness, thus dramatizing his heroic isolation as a form of martyrdom.

In the days that follow, he learns more from medical examinations and marvels at the support offered by his friends whilst wondering whether he truly deserves it. He also questions his ability to appreciate or participate in unguarded displays of emotion:

I am not lacking in gratitude, but I think I lack the capacity to love-to give myself unreservedly-to share with another the joys \& tribulations of the human condition. More \& more I seem to have withdrawn, barracked myself from other people. $(27.10 .1975 ; 27)$

The evocation here of walls or barriers to social interaction were longestablished since the beginning of Vaughan's journal-writing, with such images as the impenetrable 'citadel' of a person's character recurring in the wartime volumes. ${ }^{24}$ Likewise, the question as to whether he could ever truly love (again) had been a productive line of enquiry for decades, yet this long, eloquent, and deeply confessional journal entry's harkening back to familiar territory is sharply undercut by what follows in the same entry:

the prospect of the future absolutely appals \& terrifies me [...] when I view it straight on I would rather be dead. If I thought it might be an experience which I could turn to some use, in art or literature, that would be different. But just drawling out words which no one will ever want to read (although they may, alas, have to) is no good. (30)

This self-deprecation and downplaying of the journal is nothing newhe had on many occasions scolded himself for pretensions to fine writing or attempting to contribute to 'the treasures of literature'-but the desire he expresses to step out of time by dying, and his rejection of any notions of present or imminent productivity, is striking. ${ }^{25}$ Shortly after this entry, Vaughan was admitted to hospital for his colostomy operation. He records this stay in his journal, noting the contradictory advice of doctors and nurses but also begrudgingly praising them on occasion. 
In the journal entry dated 6 March 1976, the day he receives the news of his mother's death in hospital, Vaughan reflects on the event with a revealing sense of resignation. Figuring death as no tragedy but rather something akin to justice, he writes: 'She died at 4.10. So one problem ends \& another begins. [...] I cannot pretend to feel grief. Only relief that a useless life has ceased. Perhaps she has the peace now she was always seeking from childhood.' (67). Here he weighs the usefulness of life and finds nothing of worth to justify it being prolonged, in doing so implying the efficacy of assessing life and death in such terms and gesturing towards the eventual weighing of his own life. Four days later, following his mother's cremation, and when he had re-read a letter she had written to him in 1962 which she enclosed with her will, Vaughan writes, 'If only she had died then \& been spared the long burden of the last declining years when she knew she was a burden to herself \& everyone else.' (10.03.1976; 68 ). The resentment towards his mother's long life, and what Vaughan perceived to be her lack of true living throughout, would not only have been sharpened by knowledge of his own potentially fatal situation, but also by the painful fact of his younger (and only) brother's death long ago in 1940. Dick Vaughan had enlisted in the RAF but died in an aeroplane crash soon after; here was the very wasting of youthful male vitality that had informed Vaughan's conscientious objection to war, brought as painfully close as possible through familial tragedy. For Vaughan, just as Dick's death had been senseless so had his mother's long life and the stifling pressure of obligation that he felt towards her.

The rest of March 1976 is given over to short but very frequent journal entries in which Vaughan describes his depressed state, lack of energy, and absence of urge to paint. ${ }^{26}$ 'The Hell continues', he writes in early April, 'day after day. R. drives me insane with his bantering niggling aggression. I'm nearly insane anyway from sheer daily misery. I long only for sleep \& dread the next awakening' $(02.04 .1976 ; 73)$. He proceeds to consider once again suicide by gunshot, or what the consequences would be of murdering Ramsay. He closes the entry with the words, 'The charade will play itself out to the end. And pray God soon' (74). Whereas previously Vaughan could not see or conceive of an 'end', here there is the suggestion that it is known or can be reasonably assumed, a horizon coming into view. This conception of an end may have been informed by those 'last declining years' of his mother described in a previous journal entry, and a growing identification with a sense of housebound inertia and lack of purpose. In the months that follow, he laments how nothing brings him happiness and how alcohol and his medication numbs him for a time, but only so he can experience a joyless vegetable life. He still has students at the Slade School of Art, where he had been a tutor since the 
late 1950s, and social engagements with friends, but his journal marginalizes these facts to being mere notes amidst his passages on depression, pain, and the inadequacies of food as he writes all vestiges of life out of his journal. He affords more space in the journal to recording his time sitting alone in his dimly lit studio. He ponders why the American painter Mark Rothko (1903-1970) slashed himself with a razor when surely a revolver was readily available in New York $(03.07 .1976 ; 89)$. The particulars of suicide are what fascinate and frighten him, not the prospect of death itself: 'Oblivion holds no terror for me' (13.08.1976; 95-96). Hell is something that can be experienced, a kind of living death, whereas oblivion simply offers nothing.

\section{3. 'THOSE LONG DESPERATE YEARS'}

The remainder of the journal entries for 1976 portray a stultifying existence dominated by depression and speculation on methods of suicide, which persisted despite the commencement of psychotherapy in June. ${ }^{27}$ As 1977 begins, the journal entries are shorter than ever, recording only the facts of Vaughan's daily routines and discomforts. The year up to the beginning of September is covered in only seven and a half pages, with no entries written in July or August. But in September 1977, Vaughan writes two significantly longer entries that both begin very similarly by revisiting the subjects of his thwarted romantic longings during his long-distant youth.

The entry dated 8 September 1977 begins, 'I thought in bed last night about Boulanger. The French Canadian I picked up in the York Minster one night about $1944 \&$ took him home to bed' (120). Vaughan explains that Boulanger was in no condition to make love that night and how instead he simply laid down and observed his body in every detail, which he reproduces here in a long and lovingly florid passage. This young man, who Vaughan had met at a pub before taking him home at the behest of a friend, had been identified as 'Roland Boulanger' and exalted for his beauty in a journal entry dated 25 August 1942 (earlier than Vaughan has recollected), which describes the stillness of Boulanger's beauty and 'the weight and alabaster smoothness of his limbs'. ${ }^{28}$ The later journal entry in September 1977 follows suit with its pure classical imagery. Owing to the profundity of the memory, or perhaps Vaughan's re-reading of the earlier journal volumes in recent years, it describes skin 'the texture of rose petals', a navel like 'a pearl in his belly', and an aspect like 'a statue'. Appreciation of the prone or sleeping body was a recurring trope of Vaughan's earlier journal-writing, a perspective from which he could indulge his 
aesthetic appraisal of an adored young man without the encumbrance of social interaction and its demands. In this later journal entry, Vaughan's recollection of Boulanger (aptly) smelling 'of warm new bread' plays with the notion of nominative determinism, making the young man a symbol of all young men in their unfettered vitality, transcending mere personhood to embody the classically informed ideals that Vaughan had celebrated and invested in the male figure his whole life. It is not only the subject matter of this journal entry that recalls the past, but also the literary device that Vaughan has employed in its writing and that he had used to great effect in the journal-writing of decades previous, particularly the early 1940s: the framing of an autobiographical episode, usually a thwarted romantic fling, with an act (or performance) of remembrance. ${ }^{29}$ In this journal entry, Vaughan not only revisits a deeply held and treasured memory but a more playful, performative style of journal-writing that was associated with bygone years of romantic yearning and the aspirational, exploratory spirit of his youth.

The nostalgia is brutally cut short when Vaughan's recollections come to a jarring halt with the final line of the same long paragraph: 'I was told he'd been blown to pieces on the Anzio Beachhead' (121). The sentiment is clear: youth and love are both illusory things that come to an end, or more specifically that shatter on contact with the world. Boulanger is not mentioned again, as this journal entry swerves into different introspective territory with a paragraph beginning, 'I was never very good at sex.' Here Vaughan modestly claims to know nothing of the 'sophistications' of sex between men, only 'simple mutual masturbation', briefly alluding to his dalliance with a man named Moran with whom he was 'deeply in love'. The sequencing of this material following the recollection of (and revelation about) Boulanger gives this journal entry a discernible narrative structure, a progression-or, more aptly, a slow descent-from the idealism of youth, which is abruptly curtailed, through subsequent disappointments and re-routing of energy elsewhere, arriving at an admission of finality and irretrievability. Following the paragraph on Vaughan's sexual practices, a paragraph describing the sale of ' 3 of my Rimbaud gouaches' to an eminent professor (and specialist on the French poet) suggests some of the small satisfactions and gestures of appreciation that he experienced in his career as an artist. The next long paragraph begins by asking what will happen to Vaughan's 'E. T. machine', the electrical device or 'Black Box' that he had used and continually re-iterated over the years in his experiments with autoeroticism (122). He considers its development as a significant personal achievement, given the 'hours on end over the years' that helped him refine it, and reflects that it would be 'a pity if this is lost'. In the final paragraph of this journal entry, he 
posits that 'one's middle years' are when the pleasures to be derived from autoerotic practices are most apparent, before dismissing any suggestion that he is unique in his experiments or his thoughts concerning them. He indents the final line of this entry, so that it appears perfectly centred on the page with an ominous sense of finality: 'But all that is over now.'

The next journal entry, dated 10 September, begins by further rolling back time to an infatuation that dominated the pre-war years of Vaughan's youth: 'I thought of Aubrey Rix last night \& those long desperate years of frustration when I was intensely in love with him' (122). Again, Vaughan uses the framing device of a recent recollection to suggest the strength and value of the memory in the present or near past. He proceeds to recall how, when he was eighteen and working at the advertising firm Lintas, his colleague Aubrey, who was two years younger, rebuffed his advances but insisted they stay friends-a situation provoking considerable anguish on Vaughan's part. There was no apparent connection or compatibility on account of Aubrey being a 'thoroughly superficial person', yet Vaughan's attraction to him, and his frustration at being thwarted, allegedly produced symptoms of stress so severe that he had to go to hospital (123). He continues the entry by reminiscing about a delivery boy, who he could look at 'greedily' but never muster the courage to approach. These attachments are cited by Vaughan as examples of his own proclivity for pursuing futile endeavours in love and life: 'it was always the same frustrated longing \& fear of attempting to make contact.' By using his journal to look back to youthful heartache almost 50 years earlier, he also conveys how distant those days and their intensity of feeling were-even if those feelings were painful. Love and life are so distant now, merely stories to be retold to an audience of one, that such memories take on the quality of deathbed reminiscences. The end of the month saw one further paragraph-long entry prior to a five-week gap in the journal. It was picked up again with the intention of writing once more on the morning that Vaughan chose to take his own life.

\section{'I CANNOT BELIEVE I HAVE COMMITTED SUICIDE': AN ENDING}

When Vaughan's body was discovered he had fallen forward at his desk with a pen in his hand, his journal with him. The final entry he had been writing begins, ' $9.30 \mathrm{am}$. The capsules have been taken with some whiskey. What is striking is the unreality of the situation. I feel no different' $(04.11 .1977 ; 124)$. In the circumstances, this final entry reads with a remarkable clarity and immediacy. Vaughan briefly re-states his situation and decision: 'I cannot drag on another few years in this state.' Surely the 
clear, concise way in which Vaughan communicated these last moments was at least partly intended to inform those who found him of what precisely had happened. Yet the complete 61 volume journal, in the aftermath of its death with Vaughan, would offer to those who subsequently found and read it an account of Vaughan that likely differed significantly from the Vaughan that they thought they knew. The journal did not simply document the suffering and need to die that had consumed Vaughan in his final two years, but instead presented this suffering in continuity with a 38-year narrative of Vaughan's life in which he professed to have lived in greater agony than many who knew him may have ever suspected, even if they had previously read the self-edited version published in 1966. In his clear-eyed, compassionate introduction to an updated and expanded edition of Vaughan's selected journal-writing, Alan Ross acknowledges that much of the journal is 'extremely depressing to read', and likely more so for those who were close to Vaughan. ${ }^{30}$ Yet Ross also emphasises its humanity and even its humour within the many pages of inky script, documenting the inner workings and thought processes of an artist he describes as 'someone who thought long and hard, not only about technical problems but about the relevance of art to every aspect of living. ${ }^{31}$

Vaughan's journal was integral to his life as an artist; the two were intimately and inseparably joined. On this point, it is instructive to consider why the Vaughan that many knew and the Vaughan of the journal could seem so different. For a journal or diary to be productive and sustainable, it is useful for the author-subject to express a certain tension or dissatisfaction with the present, which can then be applied practically in speculating upon or determining a possible future, if the practice of journal or diary-writing is to be propelled forward and continue. The writing or making of journals and diaries, particularly literary or artistic engagements with the form, can be very much concerned with futurity; as argued by Lejeune, when writing a journal or diary 'we agree to collaborate with an unpredictable and uncontrollable future'. ${ }^{32}$ Vaughan's journal was devoted to self-construction, the continual process of becoming someone else, with all its attendant questions as to who Vaughan may or may not be tomorrow. Indeed, Vaughan often expressed disdain for those who he believed did not approach questions of the future with a similar seriousness, with those who had instead arrived at their destination or finished developing-such as his mother or Ramsay-rather than continually progressing and understanding life (and, by extension, art) in terms of process. Writing or making a journal or diary is arguably the most appropriate form for re-negotiating one's relationship with the future and for consideration of what impact the future, or a perceived lack of it, may have for the author-subject; it is therefore not surprising 
that Stephen Spender's September Journal (serialized 1940) and Simone de Beauvoir's Journal de guerre (first published, posthumously, 1990) were both commenced, like Vaughan's journal, within a few days of each other in the autumn of 1939, as war in Europe threw all plans and hopes for the future into doubt. The journal or diary weighs the past in a present moment of reflection in order to estimate a future for the authorsubject. This may be more true for those writing their journal or diary in undated notebooks, thereby fashioning their own timeline, yet even for those using pre-printed dated pages there is an extent to which they too are making 'a wager on the future', in Lejeune's words, 'a sort of abstract commitment to remain faithful to oneself' that implies a future for the author-subject and their journal or diary. ${ }^{33}$ Vaughan articulated time and again through journal-writing his disappointment with the unfulfilled potential of the past, as evidenced by an unsatisfactory present, to gesture towards a future in which he and the journal would faithfully live on together and continue to grapple productively with such problems.

By November 1977, Vaughan could only kill himself by also killing the journal, the account of his life and mind that always promised a tomorrow in which to write. The only way to kill the journal was to finally know the future: that there will be no tomorrow for Vaughan, its author-subject. He writes, 'It's a bright sunny morning. Full of life. Such a morning as many people have died on. I am ready for death though I fear it' $(04.11 .1977 ; 124)$. Vaughan suggests that he cannot be certain that the drugs will have the desired effect of killing him, that 'the whole thing may not work \& I shall wake up'. Whilst this may open the possibility of an alternative future, in which Vaughan has not died and he therefore lives to write in the journal once more, in the final few lines of his final entry he makes certain to place his present action into what will imminently be the past and close off any possibility of a future: 'I cannot believe I have committed suicide since nothing has happened. No big bang or cut wrists. 65 was long enough for me.' Vaughan's final entry trails off into a tiny, illegible scrawl as the drugs take effect: 'It wasn't a complete failure I did some good...'

\section{WORKS CITED}

Belsey, Alex. Image of a Man: The Journal of Keith Vaughan. London: Liverpool University Press, 2020.

Hastings, Gerard. Drawing to a Close: The Final Journals of Keith Vaughan. London: Pagham Press, 2012.

Hepworth, Anthony and Ian Massey. Keith Vaughan: The Mature Oils 1946-1977. Bristol: Sansom \& Company, 2012.

Lejeune, Philippe. 'The Continuous and Discontinuous.' In: Jeremy D. Popkin and Julie Rak (eds.), On Diary. Honolulu, HI: University of Hawai'i Press, 2009, 175-186. 
Lejeune, Philippe. 'The Diary as “Antifiction”.' In: Jeremy D. Popkin and Julie Rak (eds.), On Diary. Honolulu, HI: University of Hawai'i Press, 2009, 201-210.

Lejeune, Philippe. 'Rereading Your Diary.' In: Jeremy D. Popkin and Julie Rak (eds.), On Diary. Honolulu, HI: University of Hawai'i Press, 2009, 324-326.

Manguso, Sarah. Ongoingness: The End of a Diary. London: Picador, 2018.

Rak, Julie. 'Dialogue with the Future: Philippe Lejeune's Method and Theory of Diary.' In: Jeremy D. Popkin and Julie Rak (eds.), On Diary. Honolulu, HI: University of Hawai'i Press, 2009, 16-26.

Ross, Alan. 'Introduction.' In: Keith Vaughan (ed.), Journals 1939-1977. London: Faber and Faber, 2010, vii-xv.

Vaughan, Keith. 'Keith Vaughan Journals.' (8 boxes). London: Tate Archive, 'Keith Vaughan Journals' ( 8 boxes).

Vidal, Gore. Point to Point Navigation: A Memoir. London: Abacus, 2007.

\section{ABOUT THE AUTHOR}

Alex Belsey is a Visiting Research Fellow at the Centre for Life-writing Research at King's College London. His research interests include life-writing and its relationship to the visual arts; diaries, journals and experimental forms of autobiography; autofiction; and cultural narratives about artists and creativity from the nineteenth century to present. Alex is the author of the monograph Image of a Man: the Journal of Keith Vaughan (2020) from Liverpool University Press. alex.belsey@kcl.ac.uk.

\section{NOTES}

1 All references to vol. 61 of Keith Vaughan's journal are provided in parentheses in the main body of the text, in the format of (DD.MM.YYYY; p.); in instances where the date has already been specified previously, the reference will simply cite the page number/s with (p.).

2 Belsey, Alex. Image of a Man: The Journal of Keith Vaughan. London: Liverpool University Press, 2020 (11).

3 Hastings, Gerard. Drawing to a Close: The Final Journals of Keith Vaughan. London: Pagham Press, 2012 (23).

4 Vidal, Gore. Point to Point Navigation: A Memoir. London: Abacus, 2007 (1 \& 264).

5 Lejeune, Philippe. 'The Continuous and Discontinuous.' In: Jeremy D. Popkin and Julie Rak (eds.), On Diary. Honolulu, HI: University of Hawai'i Press, 2009, 175-86; 176.

6 Manguso, Sarah. Ongoingness: The End of a Diary. London: Picador, 2018 (3).

7 Lejeune, Philippe. 'The Diary as "Antifiction".' In: Jeremy D. Popkin and Julie Rak (eds.), On Diary. 201-10; 208.

8 Rak, Julie. 'Dialogue with the Future: Philippe Lejeune's Method and Theory of Diary.' In: Jeremy D. Popkin and Julie Rak (eds.), On Diary. 16-26; 24.

9 Manguso, Sarah, 2018 (93-94 \& 27).

10 Vaughan, Keith. 'Journal.' In: Keith Vaughan Journals (vol. 1; 6). London: Tate Archive.

11 Idem (1 June 1940; vol. 3; 118).

12 Hepworth, Anthony and Ian Massey. Keith Vaughan: The Mature Oils 1946-1977. Bristol: Sansom \& Company, 2012 (97).

13 This was a somewhat rare (and therefore highly significant) decision by Vaughan to directly reference a work from the Western canon of high art; in addition to this painting, 
he also exhibited a further eight pictures titled Study for Laocoön Group in 1964. The celebrated marble sculpture Laocoön and his Sons, also known as the Laocoön Group, was discovered in Rome in 1506 and subsequently became the quintessential image of agony outside of Christ's passion. For Vaughan, the Laocoön group was a subject that 'represents in supremely dramatic form man's conflict with his environment and with himself, his own body'; Hepworth, Anthony and Ian Massey, 2012 (157).

14 Vaughan, Keith. 'Journal' (23 September 1963; vol. 44; 47).

15 Idem (15 November 1963; vol. 44; 95).

16 Idem ('August Bank Holiday' [1958]; vol. 39; 5).

17 Idem (13 September 1964; vol. 46; 8).

18 Hastings, Gerard, 2012 (10).

19 Vaughan, Keith. 'In a July 1965 entry he declares that the journal has "become sordid + self indulgent, like my life".' 'Journal' (3 July 1965; vol. 47; 39).

20 Ramsay was almost always abbreviated to 'R.' in Vaughan's journal. Given that an initial is the flimsiest possible disguise with which to anonymise the subject of Vaughan's ire, this practice of abbreviation may be as much about diminishing and dismissing Ramsay; similarly, Vaughan would refer to his mother, another source of burden and annoyance, simply as ' $M$ '.

21 Ramsay would die from liver complications in 1981 and Hastings speculates that by 1975 he was already suffering from the complaint that would ultimately kill him; Hastings, Gerard, 2012 (45).

22 Ramsay is explicitly called 'a cancerous growth' in the later journal entry dated 10 February 1976 (64).

23 Vaughan writes in his journal that Alan Ross is 'as good a person as any' (09.01.59; vol. $40,46)$; this is perhaps an understatement, considering Ross's reputation as man of letters who would soon become the editor of the London Magazine in 1961.

24 For example, Vaughan refers to the citadel of my character' $(11.03 .40 ;$ vol. 2,150$)$ and 'the battlements of my own citadel' (05.07.40; vol. 3, 208).

25 Vaughan, Keith. 'This is intended for a journal, not a contribution to the treasures of literature.' 'Journal' (5 August 1940; vol. 3; 273).

26 It would be disingenuous to suggest that, at this point, Vaughan was finished as a painter, for 1976 saw the completion of his Ninth Assembly of Figures, the last in the lifelong series, and Mallarmé's Garden II, which was an inspired evolution of the decade's work on landscapes and garden pictures. Nevertheless, the journal documents a period in which the libidinous urge and philosophical energy that propelled Vaughan as a painter was largely and distressingly absent. Hastings considers Vaughan's picture Adam (1976) as reflecting 'something of Vaughan's physical impotence and emotional sterility' at the time; Hastings, Gerard, 2012 (144).

27 Vaughan had commenced psychotherapy with someone he refers to as 'Gallway', having been advised of its potential helpfulness by friends Patrick Woodcock and Bob Gosling.

28 Vaughan, Keith. 'Journal' (vol. 13; 7).

29 In a very early instance, Vaughan opens a journal entry by describing how 'a precious Faber publication, nicer to the touch and eye than the intellect, reminds me of the day I went to Chamonix'; this sets the scene for the following eight pages consisting of a detailed autobiographical episode, at the centre of which is a failed advance made towards a young man; Vaughan, Keith, 'Journal' (31 January 1940; vol. 2; 49).

30 Ross, Alan. 'Introduction.' In: Keith Vaughan (ed.), Journals 1939-1977. London: Faber and Faber, 2010, vii-xv; xiii.

31 Idem (viii).

32 Lejeune, Philippe. 'The Diary as "Antifiction”' (208).

33 Lejeune, Philippe. 'Rereading Your Diary.' In: Jeremy D. Popki and Julie Rak (eds.), On Diary. 324-26; 324. 